\title{
Effect of Kinetin and Zinc Foliar Spray on Growth Performance of Clivia miniata. L. Plant.
}

\author{
El-Bably, Samia M. Z ${ }^{1}$, Nahed, M. Rashed ${ }^{2}$ \\ ${ }^{1}$ Ornamental Plants and Landscape Gardening Research Department, Horticulture Research Institute, \\ Agriculture Research Center, Giza, Egypt \\ E-mail address: sa elbably@yahoo.com \\ ${ }^{2}$ Vegetable and Ornamental Department, Faculty of Agriculture. Damietta University, Damietta, Egypt \\ E-mail address: rashed nahed@du.edu.eg
}

\begin{abstract}
Experiment was conducted at Sakha Horticulture Research Station, Kafr El-Sheikh Governorate, Egypt, during the two successive seasons of 2014/2015 and 2015/2016 to study the effect of foliar spray with kinetin and zinc on Clivia miniata, L. plant for improving growth performance and raising new formed rhizomes. Kinetin and zinc were sprayed after three weeks of planting, three times, with three weeks' interval at the rates of $0,30,60$ and $90 \mathrm{mg} / \mathrm{L}$ for kinetin and 0,100 and $150 \mathrm{ppm}$ for zinc sulphate. Results indicated that application of kinetin at the rate of $90 \mathrm{ppm}$ coupled with zinc at the rate of $150 \mathrm{ppm}$ significantly increased leaf length by $45.65 \%$, number of leaves by $49.40 \%$, fresh weight of leaves/plant by $57.85 \%$, dry weight of leaves/plant by $56.90 \%$, precocity in flowering by $35.17 \%$, flowering stalk length by $34.47 \%$, flowering stalk diameter by $41.89 \%$, flowering stalk fresh weight by $66.11 \%$, flowering stalk dry weight by $64.84 \%$, number of florets/flower by $57.79 \%$, number of flower/clump by $60.77 \%$ and flowering duration by $47.89 \%$ and number of rhizomes/clump by 66.6 as well as fresh and dry weights of rhizomes/ clump by 34.38 and $56.79 \%$ respectively. In addition, root length was increased by $55.27 \%$, number of roots by $48.72 \%$ as well as fresh and dry roots by 60.07 and $38.59 \%$ respectively. Besides, it increased chemical constituents i.e. nitrogen, phosphorus, potassium, chlorophyll (a), chlorophyll (b), carbohydrates content in leaves by 51.73, 51.62, 38.99, 58.36, 41.55 and 30.45\%, respectively, compared to untreated plants. Therefore, application of kinetin at the rate of $90 \mathrm{ppm}$ coupled with zinc at the rate of $150 \mathrm{ppm}$ after three weeks of planting Clivia miniata. L. three times with three weeks' interval improved growth performance and raised new formed rhizomes/ clump under local conditions.
\end{abstract}

keywords: Kinetin, Zinc and Clivia miniata $\mathrm{L}$.

\section{INTRODUCTION}

Clivia miniata. L. (Amaryllidaceae) is one of the best-known ornamental plant groups worldwide (Koopowitz, 2002). It has a good economic potential for pot plant trade. It is extremely popular as a garden plant. The orange flowers are produced in dense clusters on top of a thick stem that pushes up from between a fan of evergreen, strap-like leaves. In addition, it has also been reported to have medicinal value. It is considered poisonous because it contains small amounts of the alkaloid lycorine. However, large quantities must be ingested to cause symptoms of toxicity. Lycorine has many derivatives used for anti-cancer (Wang et al., 2014 and Zhifei et al., 2013). Offset and rhizomes division are the important methods of vegetative propagation for Clivia miniata L plant. Although the offset production rate in this plant is not enough for commercial production, the slow rate of offset production is a serious obstacle in developing $\mathrm{C}$. miniata. L. cultivation

kinins are plant growth regulators used for stimulating cell division, as well as for the formation and growth of axillary and shoots. The main group of synthetic cytokines includes N6 substituted adenines like kinetin (6furfurylaminopurine), benzyl adenine (6- benzylaminopurine, BA), 6-benzylamino-9(tetrahydropyran-2-yl) -9H- purine; PBA (Bubán, 2000). Many authors demonstrated that growth and flowering of many ornamental plants can easily be forced by different cytokinin groups. Mohamed (2017) revealed that the application of Benzyl adenine at $100 \mathrm{ppm}$ gave the high quality of vegetative, flowering and chemical composition characteristics of Aster (Symphyotrichum novibelgii). Bezabih et al., (2017) on Zingiber officinal revealed that 6-benzylaminopurine at the rate of $50 \mathrm{ppm}$ increase leaf length, number of leaves, rhizome weight and increase bud development hence propagate production ratio.

On Carnation Ramtin et al., (2016) indicated that chlorophyll (a) and (b) content, significantly affected by using Benzyl adenine as foliar spray at the rate of $150 \mu \mathrm{M}$. Aier et al., (2015) on Gladiolus plant indicated that $\mathrm{BA}$ at $250 \mathrm{ppm}$ exhibited maximum economic yield in terms of number of spikes per corm and number of corms per plant. Ghatas (2015) on Hemerocallis aurantiaca indicated that the three concentrations of kinetin increased vegetative growth parameters i.e., number of leaves/plant, fresh and dry weights of leaves/plant and number of offsets/clump .In addition to improving flowering growth parameters i.e., number 
of days required from planting to start flowering, number of flower, flower stalk length, diameter, fresh and dry weights of flower stalk, duration of flower on plant and flower vase life positively were affected, as the same as chemical composition parameters i.e., leaf total carbohydrates , N, P and $\mathrm{K}$ contents with superior to the medium and high rates. Youssef and Abd El-Aal (2014) indicated that 60 ppm kinetin-sprayed plants improved most of the studied vegetative and flowering growth traits of Hippeastrum vittatum plants. Sardoei et al., (2013) found that application of benzyl adenine at the rate of $400 \mathrm{mg} / \mathrm{L}$ either foliar or drench gave the maximum offset of Aloe barbadensis. Youssef and Mady (2013) showed that spraying Aspidistra elatior plants with benzyl adenine at $75 \mathrm{ppm}$ improved all vegetative growth and chemical constituents. Eid et al., (2010) indicated that parameters of flowering characteristics, number of bulblets/plant and fresh weight of bulb and bulblets / plant were significantly increased by foliar application of benzyl adenine of Polianthus tuberosa. Youssef and Ismaeil (2009) indicated that 200 ppm kinetin-sprayed plants improved all studied vegetative and flowering growth traits of Clivia miniata plants. Mohamed (2009) on Polianthus tuberosa showed that, the treatments of BA at 50 ppm and kinetin at 50,100 and 200 ppm recorded highly increases of fresh weight of total flower spike, fresh weight of flower spike with floret, fresh weight of flower spike without floret, fresh weight of third floret, number of florets per spikes, length of flower spike, thickness of flower spike, dry weight of total flower spike, dry weight of flower spike with floret, dry weight of flower spike without floret and dry weight of the third floret of tuberose and bird of paradise. In addition to increased N, P, K, chlorophyll (a) and (b) and total carbohydrates.

Eid and Abou-Leila (2006) reported that application of benzyladenine on Caroton plant resulted an increases in plant growth (fresh weight, plant height, No. of branches). Youssef et al. (2004) reported that foliar application of kinetin to Matthola incana L. plants significantly promoted growth.

Zinc is one of the essential micronutrients required for optimum crop growth. It plays an important role in many biochemical reactions (carbohydrate, proteins, fats and oil metabolism) within the plants and in the energy transfer mechanism. Zinc is important in the formation of the growth hormone auxin. Auxin is produced by shoot tips and controls cell division, leaf and shoot growth and fruit development. Zinc is also needed by leaf cells to form the green leaf pigment chlorophyll. It regulates the starch formation and proper root development. Also, zinc plays an essential role in plant physiology where it activates some enzymes such as dehydrogenases, pretenases, peptidases and phospho hydrolases. It does not only improve the yield but also improves the quality of crops (Sharma, 2014 and Maerschel et al., 2007). Devil et al., (2017) on Polianthes tuberosa noticed that foliar application of $\mathrm{ZnSO}_{4}$ at $0.5 \%$ gave maximum number of leaves/plant, plant height, number of spike/plant, spike length, number of florets/spike, number of bulbs/clump, weight of bulbs/clump, diameter of the largest bulb. Neetu et al., (2016) on gladiolus cv. Gunjan, Gold, Sabnum and Snow princess pointed out that the application of kinetin at the rate of 100, $150 \mathrm{ppm}$ and $200 \mathrm{ppm}$ significantly increased vegetative growth, and flowering parameters. Shah et al., (2015) revealed that application of zinc sulphate at $0.5 \%$ on Tagetes erecta increased significantly vegetative growth parametares i.e. plant height, number of leaves/ branches and number of branches/ plant. Also, affected flowering traits i.e. stem diameter, number of flowers plant, and flower fresh weight. Hembrom and Singh (2015) on Lilium indicated that treatment of foliar zinc sulphate at $0.4 \%$ significantly enhanced the number of bulblets per plant over control treatment. Khalifa et al., (2011) on Iris concluded that the foliar spray of zinc sulphate at all rates significantly increased growth parameters, flowers characteristics and bulblet number as compared with the control treatment. The treatments also significantly increased leaves carbohydrate, pigments, $\mathrm{N}, \mathrm{P}$ and $\mathrm{K} \%$. Reddy and Rao (2011) on gladiolus showed that the treatment $2 \%$ zinc significantly increased plant height, number of leaves, leaf length with the highest values when sprayed at 6 weeks after planting compared to 4 and 8 after planting, gave more number of spikes, spike length, number of florets per spike and highest spike growth rate over other treatments. Eid et al., (2010) showed that zinc at $0.75,1.50$ and $3 \mathrm{~g} / 1$ or BA at 25 , 50 and $100 \mathrm{ppm}$ as foliar application significantly increased flowering, bulbs characteristics, N, P, K, and total carbohydrates content of tuberose.

Offset and rhizomes are the important methods of vegetative propagation for Clivia miniata, L. plant. Also, the offset production rate in this plant is not enough for commercial production, the slow rate of offset production is a serious obstacle in developing C. miniata L. cultivation. Therefore, offset production, duration and quality flowering should be increased. In addition, information regarding micro nutritional requirements is lacking for C.miniata L. Due to these reasons, using agronomy practices like growth regulators (kinetin) and micronutrients (zinc) seems to be necessary in order to produce a lot of plants and flowers in minimum time. Therefore, this experiment was performed to study the effect of kinetin $\left(\mathrm{C}_{10} \mathrm{H}_{9} \mathrm{~N}_{5} \mathrm{O}\right)$, zinc sulphate $\left(\mathrm{ZnSO}_{4}\right)$ as EDTA $16 \%$ at different rates and the interaction between them to enhance 
growth performance, flowering, rhizomes productivity and some chemical constituents of Clivia miniata.L. plant.

\section{MATERIALS AND METHODS \\ Experimental site}

This experiment was conducted at Sakha Agricultural Research Station, Kafr El-Sheikh Governorate, Egypt, located at 31- 57 latitude, 3057 longitude with an elevation of about 6 meters above mean sea level in the North Middle Nile Delta region during the two successive seasons of 2014/2015 and 2015/2016 under saran house.

\section{Planting procedure}

Rhizomes of Clivia miniata,L. a local variety, three years old, at weight of 130-150 (g) were obtained freshly from Faculty of Agriculture at Kafr El-Sheikh University. On October $28^{\text {th }}$, rhizomes were immersed in fungicide solution, then, they were planted in clay pots of $30 \mathrm{~cm}$ diameter containing a growing media of sand and clay (1: 2 $\mathrm{v} / \mathrm{v})$ at $10-12 \mathrm{~cm}$ depth of soil in saran house. Soil samples were taken for physical and chemical analysis before planting in the two seasons. The obtained data are shown in Table (A).

The plants were fertilized with kristalon (20:20:20) at $4 \mathrm{~g} / \mathrm{l}$. Fertilizers were devoted into three equal portions, the first one was added after one-month of planting, and the second one applied a month later, while the third one was applied during flowering. Kinetin and zinc were applied as foliar spray after 3 weeks from planting, three times, at three weeks' interval. The plants of each treatment were sprayed till run off point. However, control treatment was sprayed with tap water.

Experimental design:

The pots experiment was laid out in a factorial treatment combination in a completely randomized block design under saran house. The two-factors were consisted of four concentrations of kinetin which were $0,30,60$ and $90 \mathrm{mg} / 1$ and as the first factor zinc treatments with three level of 0,100 and150 mg/l as the second factor. Three replicates were used, each replicate consisted of four pots and every pot contained one plant (4 kinetin x 3 zinc $\times 3$ replicates $\mathrm{x} 4$ pots) as follow:

\begin{tabular}{|c|c|}
\hline $\begin{array}{l}\text { Kinetin } \\
\left(\mathrm{C}_{10} \mathrm{H}_{9} \mathrm{~N}_{5} \mathrm{O}\right) \\
\text { treatments }\end{array}$ & $\begin{array}{c}\text { Zinc sulphate }\left(\mathrm{ZnSO}_{4}\right) \\
\text { treatments }\end{array}$ \\
\hline $\begin{array}{l}\text { 1- Control sprayed } \\
\text { with tap water } \\
(0 \text { kinetin })\end{array}$ & $\begin{array}{l}\text { 1- Control sprayed with tap } \\
\text { water (0 zinc). } \\
\text { 2- Zinc sulphate sprayed at } \\
100 \mathrm{mg} / 1 \\
\text { 3- Zinc sulphate sprayed } \\
\text { at } 150 \mathrm{mg} / \mathrm{l} \text {. }\end{array}$ \\
\hline $\begin{array}{l}\text { 2- Kinetin sprayed } \\
\text { at } 30 \mathrm{mg} / 1\end{array}$ & $\begin{array}{l}\text { 1- Control sprayed with tap } \\
\text { water ( } 0 \text { zinc). } \\
\text { 2- Zinc sulphate sprayed at } \\
100 \mathrm{mg} / \mathrm{l} \text {. } \\
\text { 3- Zinc sulphate sprayed at } \\
150 \mathrm{mg} / \mathrm{l} \text {. }\end{array}$ \\
\hline $\begin{array}{l}\text { 3- Kinetin sprayed } \\
\text { at } 60 \mathrm{mg} / 1\end{array}$ & $\begin{array}{l}\text { 1- Control sprayed with tap } \\
\text { water }(0 \text { zinc }) \text {. } \\
\text { 2- Zinc sulphate sprayed at } \\
100 \mathrm{mg} / \mathrm{l} \text {. } \\
\text { 3- Zinc sulphate sprayed at } \\
150 \mathrm{mg} / \mathrm{l} \text {. }\end{array}$ \\
\hline $\begin{array}{l}\text { 4- Kinetin spr } \\
\text { at } 90 \mathrm{mg} / \mathrm{l} \text {. }\end{array}$ & $\begin{array}{l}\text { 1- Control sprayed with tap } \\
\text { water }(0 \text { zinc }) \text {. } \\
\text { 2- Zinc sulphate sprayed at } \\
100 \mathrm{mg} / \mathrm{l} \text {. } \\
\text { 3- Zinc sulphate sprayed at } \\
150 \mathrm{mg} / \mathrm{l} \text {. }\end{array}$ \\
\hline \multicolumn{2}{|c|}{$\begin{array}{l}\text { Kinetin stock solution preparation } \\
\text { Kinetin was solved by sodium hydroxide, and } \\
\text { prepared stock solution }(1000 \mathrm{mg} / \mathrm{l}) \text { then, it was } \\
\text { diluted to obtain the required concentrations }(30,60 \\
\text { and } 90 \mathrm{mg} / \mathrm{l}) \text { with addition of Tween- } 20 \text { at the } \\
\text { concentration of } 0.1 \% \text { as surfactant. }\end{array}$} \\
\hline
\end{tabular}

The following data were recorded:

Vegetative growth parameters were measured such as leaf length $(\mathrm{cm})$, leaf number /plant, leaves fresh and dry weights/plant (g). Also, flowering growth parameters were measured such as flowering date as number of days from planting to the first flower bud open, flowering stalk length $(\mathrm{cm})$, flowering stalk diameter, flowering stalk fresh and dry weights (g/plant), number of florets/flower, number of flowers/ clump and duration of flowers (day), as well as rhizome growth parameters i.e. number of produced offsets/clump, fresh and dry weights of rhizome/ clump (g), roots length, roots number /clump as well as, roots fresh and dry weights/ clump.

Table A: Physical and chemical analysis of soil before planting in the two seasons according to Page (1982).

\begin{tabular}{|c|c|c|c|c|c|c|c|c|c|}
\hline \multicolumn{10}{|c|}{ Physical analysis } \\
\hline Sand & & & & & lay & \multicolumn{4}{|c|}{ Texture } \\
\hline $48 \%$ & & & & & $2 \%$ & \multicolumn{4}{|c|}{ Sandy clay loam } \\
\hline \multicolumn{10}{|c|}{ Chemical analysis } \\
\hline $\mathbf{p H}$ & $\mathrm{EC} \mathrm{dSm}^{-1}$ & $\mathrm{Na}^{+}$ & $\mathbf{K}^{+}$ & $\mathrm{Ca}^{++}$ & $\mathbf{M g}^{++}$ & $\mathrm{CO}_{3}^{--}$ & $\mathrm{HCO}_{3}{ }^{-}$ & $\mathrm{Cl}^{-}$ & $\mathrm{SO}_{4}^{--}$ \\
\hline 8.2 & 1.91 & 8.8 & 0.8 & 3.8 & 5.7 & - & 11.4 & 5.9 & 1.8 \\
\hline
\end{tabular}



However, data concerning vegetative growth and flowering were recorded at flowering time on March, while those of rhizome productivity and roots were measured after the end of the flowering duration i.e. May $15^{\text {th }}$.

\section{Chemical analyses:}

Percentages of $\mathrm{N}, \mathrm{P}$, and $\mathrm{K}$ of dried leaves were determined at the end of the experiment according to Piper, (1947), Troug and Meyer (1939) and Brown and Lilliland, (1946), respectively. Chlorophylls (a) and (b) were determined in leaf samples (mg/g f.w) according to colorimetric method (A.O.A.C, 1990). And total carbohydrates content (mg/g dry weight) of leaf using the colorimetric method given by Herbert et al., (1971).

\section{Statistical analysis:}

Data were computed and subjected to analysis of variance (ANOVA) by adopting factorial combination in a completely randomized block design. Duncan's multiple range test was used for the comparison between means of treatments according to Snedecor and Cochran, (1972).

\section{RESULTS AND DISCUSSION}

\section{A. Vegetative growth parameters:}

All kinetin treatments resulted in a significant increment in leaf length, leaf number/plant and leaves fresh and dry weight/plant comparing the control treatment in both seasons regardless zinc treatments as shown in Table (1). Kinetin at the rate of $90 \mathrm{mg} / \mathrm{l}$ gave the maximum growth parameters in the two seasons. Moreover, the highly concentration of kinetin promoted leaf length by 30.31 and $29.88 \%$, leaf number /plant by 39.88 and $41.05 \%$, leaves fresh weight by 36.86 and $44.10 \%$ and leaves dry weight by 45.26 and $43.33 \%$ comparing to the control treatment in the two seasons, respectively. This was primarily due to the role of kinetin in stimulation of the cell division, enlargement and cell number (Khalighi et al., 2005 and Schmulling, 2002). The current findings were concided to (Neetu et al., (2016), Ghatas (2015), Sardoei et al., (2013), Youssef and Mady (2013) and Youssef and Ismaeil (2009) as they observed that kinetin increased vegetative growth of leaf number/plant, fresh and dry weights of leaves/plant.

Referring to zinc treatments, it was clear that application of zinc significantly stimulated all vegetative growth parameters over untreated one (Table 1). The highly concentration of zinc application $(150 \mathrm{mg} / \mathrm{l})$ recorded the highest leaf length, leaf number/plant and leaves fresh and dry weight/plant without significant differences for lower concentration of $100 \mathrm{mg} / \mathrm{l}$ in some cases during the two seasons. These increasing may be attributed to the effects of zinc on major metabolic processes, as well as regulation of the cell division, cell cycle, the formation of the growth hormone auxin that produced by shoot tips, and controls leaf and shoot growth (Kocot et al., 2011 and Maerschel et al., 2007).

These results are in corroboration with the earlier findings of (Hembrom and singh (2015), Fahad et al., (2014), Khalifa et al., (2011), Reddy and Rao, (2012) and Halder, et al., (2007a) as they further reported that micronutrients applied to various bulbs as foliar spray enhanced vegetative growth characters.

Regarding the interaction between application of kinetin and zinc treatments throughout the two experimental seasons presented in Table (1), the highest growth parameters were observed from the sprayed plants with combination of kinetin at the rate of $90 \mathrm{mg} / \mathrm{l}$ and zinc $150 \mathrm{mg} / \mathrm{l}$ in the two seasons. However, this treatment enhanced leaf length by 52.7 and $38.6 \%$, leaf number /plant by 47.8 and $51.0 \%$, leaves fresh weight by 49.9 and $65.8 \%$ and leaves dry weight by 57.5 and $56.3 \%$ comparing to the control in the two seasons, respectively.

\section{B. Effect on flowering parameters:}

It is distinct from data presented in Table (2) that, the different kinetin treatments caused a steady and significant increase in all flowering stalk parameters by increasing kinetin rates which promoted stalk length by 27.87 and $27.22 \%$, stalk diameter by 40.65 and $40.51 \%$, stalk fresh weight by 53.92 and $56.97 \%$ and stalk dry weight by 46.76 and $56.72 \%$. Data presented in Table (3) indicated also that application of kinetin at the rate of $90 \mathrm{mg} / \mathrm{l}$ caused earlier flowering by 37.4 and $38.6 \%$ compared with untreated plants throughout both seasons, respectively. Moreover, number of florets/flower was gradually and significantly increased by 47.80 and $40.53 \%$, number of flowers/clump by 50.00 and $52.38 \%$ and flowering duration 35.06 and $38.69 \%$ in the first and second seasons respectively. These increments may be attributed to that kinetin can delay senescence and cause transport of many solutes from older parts of the leaves or even from older leaves into the treated zone (Salisbury and Ross, 1974). In accordance with these results were those reported by Neetu et al., (2016), Ghatas, (2015), Sable et al., (2015), Youssef and Abd El-Aal, (2014), Eid et al., (2010 )and Youssef and Ismaeil (2009).

Regarding the effect of zinc treatments, it is clear from Table (2) that application of zinc at the rate of 150 $\mathrm{mg} / \mathrm{l}$ significantly increased the flowering stalk length, stalk diameter, as well as fresh and dry weights in comparison to control treatment. These results are in harmony with those of Youssef and Abd El-Aal, (2014), Khalifa et al., (2011), Reddy and Rao, (2012) and Eid et al., (2010).

It is noteworthy, that high zinc concentration $(150 \mathrm{mg} / \mathrm{l})$ increased precocity of flowering by 13.6 and $9.1 \%$, number of florets/flower by 26.26 and $29.26 \%$, number of flowers/ clump by 23.53 and $21.06 \%$ and flowering duration by 22.22 and $16.55 \%$ during both seasons, respectively, over the control treatment as shown in Table (2). 



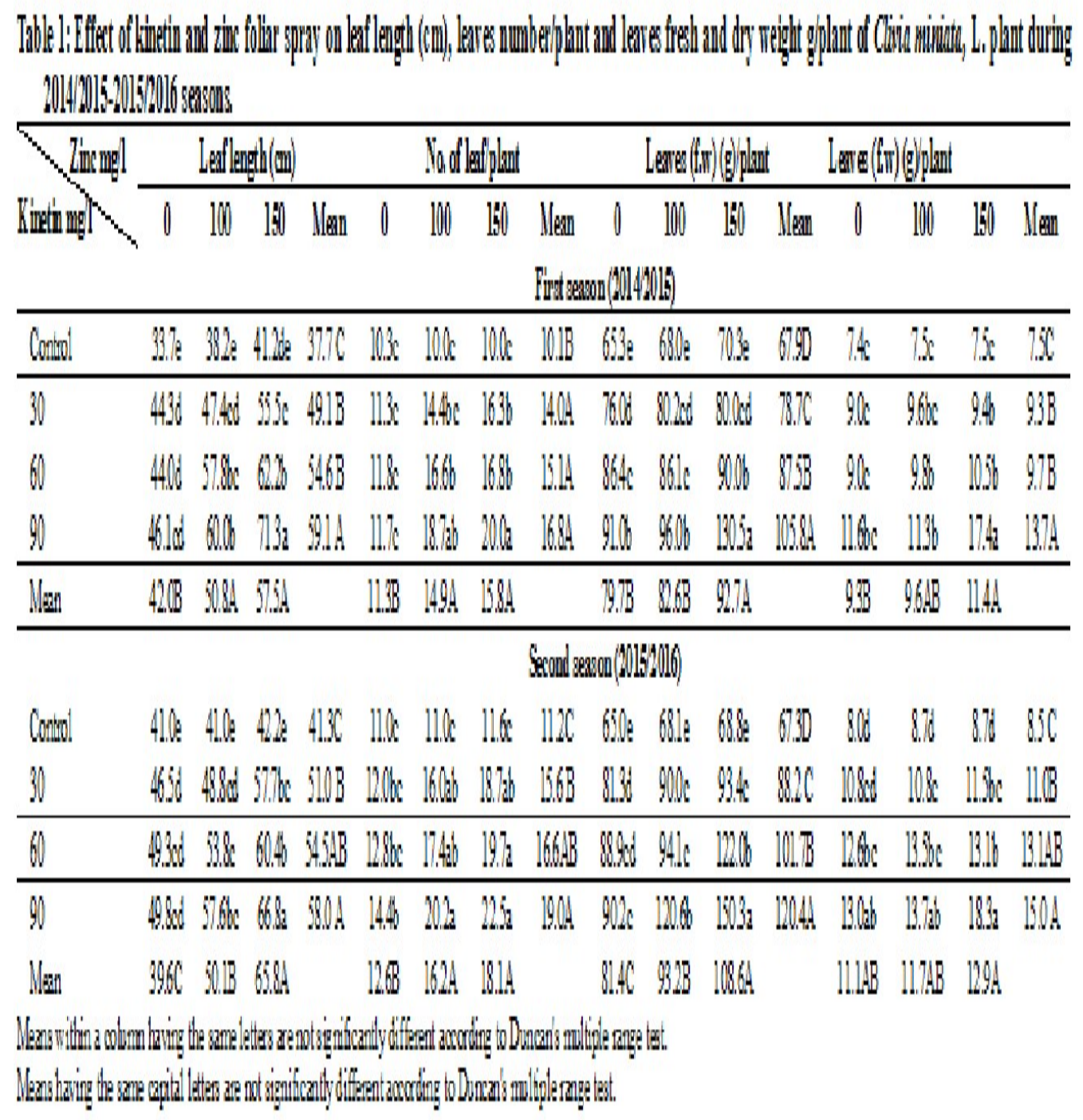




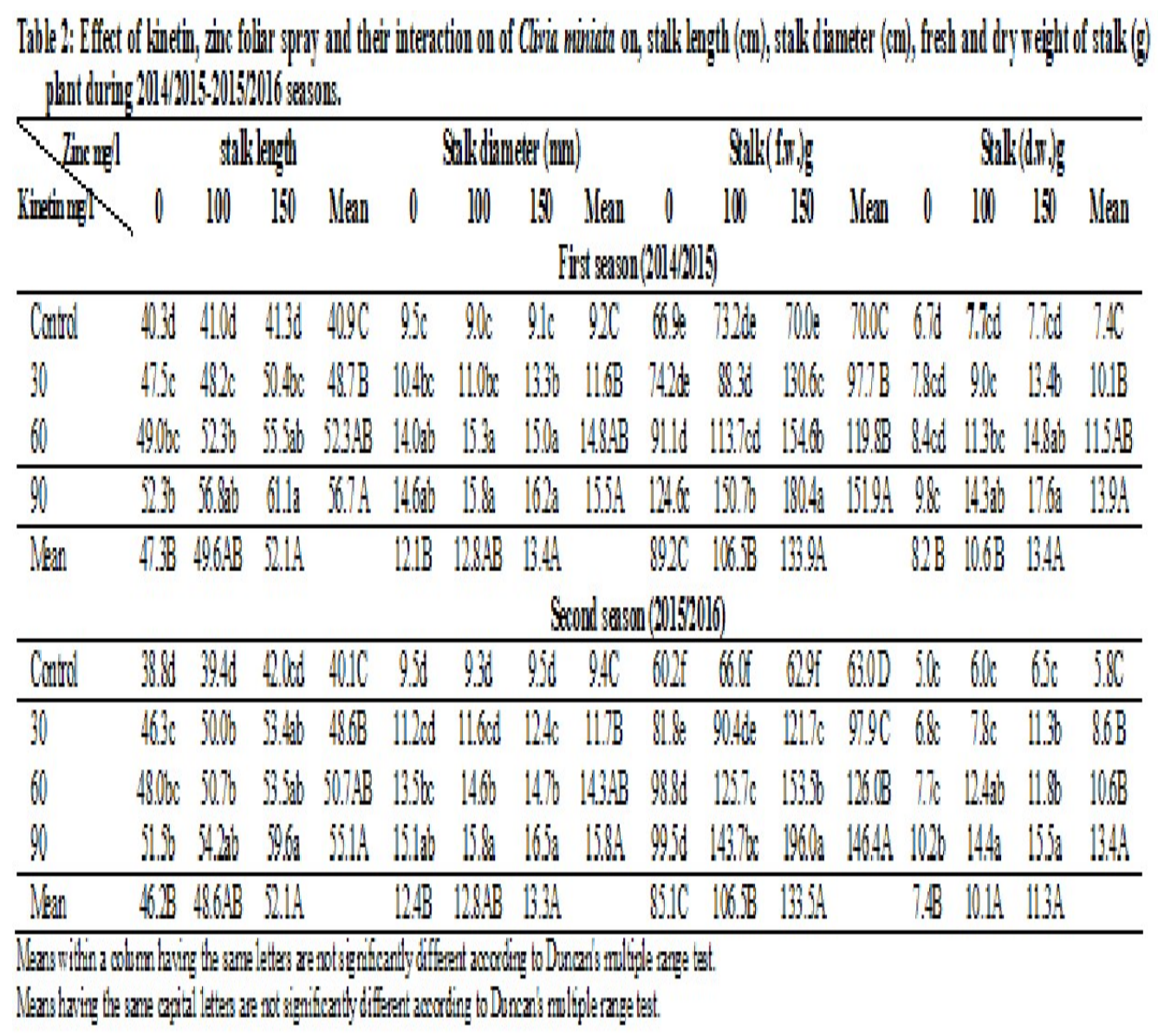




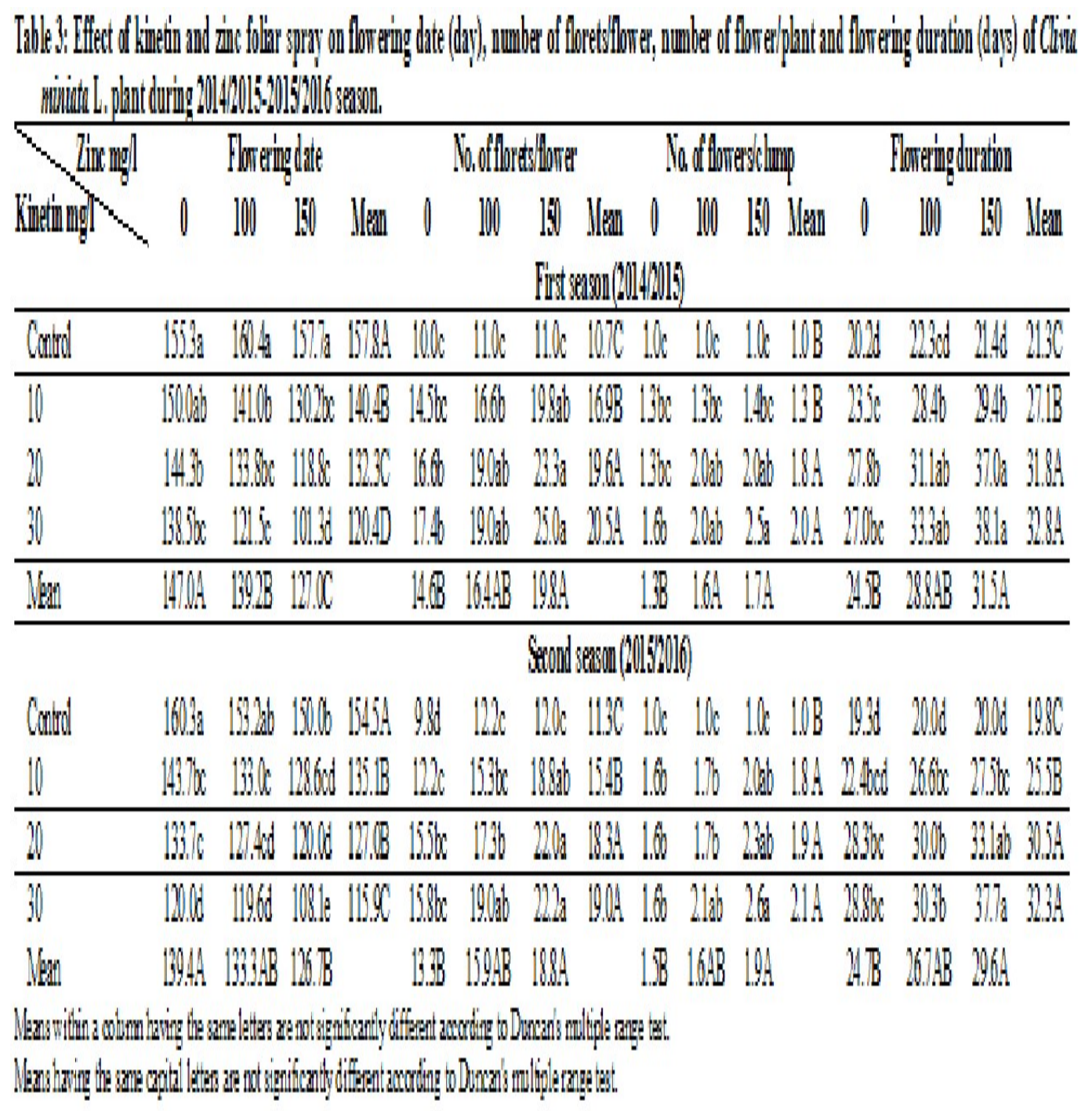


The reason for early flowering and extended duration flower may be due to the fact that zinc promotes flower setting and helps in proper development of flowers (Devil et al., 2017).

The improvement of flowering traits may be could be attributed that zinc plays a role in protein synthesis as evidenced by the accumulation of soluble nitrogen compounds such as amino acids and amides. Zinc participates in the biosynthesis of the plant auxin indole-3-acetic acid (Jamieson1983) Which reflected on vegetative growth, then flowering characters. These findings were in agreement with those of shah et al., (2015), Reddy and Rao, (2012) and Eid et al., (2010).

As regards the interaction between the two studied factors, it is obvious that the combination between kinetin $(90 \mathrm{mg} / \mathrm{l})$ and zinc $(150 \mathrm{mg} / \mathrm{l})$ gave the highest record for both seasons. The combination of zinc and kinetin contributed more than their single application as increased flowering stalk length by 34.04 and $34.89 \%$, stalk diameter by 41.36 and $42.42 \%$, stalk fresh weight by 62.93 and $69.29 \%$ and stalk dry weight by 61.93 and $67.74 \%$, earlier flowering by 37.77 and $32.56 \%$ compared with untreated plants throughout both seasons, respectively. Moreover, a gradual and significant increment percent for number of florets/flower was 60.00 and $55.58 \%$ and 60.00 and $61.54 \%$ for number of flowers /clump and 46.98 and $48.81 \%$ for flowering duration. These results may be attributed to micronutrients like zinc perform a specific role in plant growth like leaf number which, considered as an important factor in growth, responsible for photosynthesis and ultimately affecting the flower yield and quality, development and also helps in production of the quality produce. In addition, cytokinin is a hormone which can increase flowering production in many plants (Carey et al., 2008). These results are in harmony with those of Abd El-Aziz and Balbaa, (2007) and Eid et al., (2010).

\section{Effect on rhizomes and roots growth parameters:}

Clivia miniata. L bulbs grow slowly and offset formation rate is slow in them. Data presented in Table (4) indicted that all kinetin rates significantly increased number of offsets per plant, fresh and dry weights of rhizomes/clump. Foliar spray of kinetin at the rate of 90 $\mathrm{mg} / \mathrm{l}$ increased number of offset by 58.33 and $60.00 \%$, fresh weight of rhizomes/ clump by 33.40 and $33.24 \%$ and dry weight of rhizomes/ clump by 35.83 and $49.12 \%$ over the control treatment in the two seasons, respectively. Data presented in Table (5) also illustrates all root parameters i.e. root length, number of roots/clump, fresh weight of roots/ clump and dry weight of roots/clump as affected by application of all kinetin treatments compared to control treatment. The highest rate of kinetin $(90 \mathrm{mg} / \mathrm{l})$ increased root length by 41.37 and $45.45 \%$, number of roots by 50.20 and $40.75 \%$, fresh weight of roots/clump by 52.00 and $46.85 \%$ and dry weight of roots/clump by 37.85 and
$28.65 \%$ in the first and second seasons respectively. Increasing offsets number can be attributed to the role of kinetin on promoting protein synthesis, increasing cell division and enlargement (Cheema and Sharma, 1982). These results are in harmony with those of Aier et al., (2015), Hembrom and Singh (2015), Ghatas, (2015) and Sardoei et al., (2013). Spraying cytokinins on Hemerocallis can increase offset production via affecting cell division, offsets size and growth by stimulating lateral bud's growth (Amling et al., 2007).

Concerning the effect of zinc treatments on rhizome growth parameters i.e. number of offset per plant, fresh and dry weight of rhizomes/clump. Data illustrated in in Table (4) revealed that the high rate of zinc $(150 \mathrm{mg} / \mathrm{l})$ gave the highest values of offset production as well as fresh and dry weights of rhizomes/ clump as compared to control treatment in both seasons.

Similar trends in roots parameters in both seasons were obtained as shown data presented in Table (4). As for the importance of zinc in plant structure and in physiological processes, it improves growth including, rhizome offset and rhizome production. These results are in a parallel line with those of Fahad et al., (2014), Sharma, (2014), Khalifa et al., (2011) and Kumar et al., (2003).

Regarding the interaction between the two factors, it is obvious from data presented in Table (5) that, all rhizomes and roots parameters were significantly raised by the application of combination of kinetin at the rate of $90 \mathrm{mg} / \mathrm{l}$ and zinc at the rate of $150 \mathrm{mg} / \mathrm{l}$. Besides, number of offset per plant was raised by $66.6 \%$ in each seasons, fresh weight of rhizomes/ clump by 43.42 and $43.33 \%$, dry weight of rhizomes/ clump by 55.89 and $57.69 \%$, root length by 50.77 and $59.76 \%$, number of roots/ rhizome 52.25 and $45.18 \%$, roots fresh weight by 60.85 and $59.28 \%$ and roots dry weight by 41.15 and $36.27 \%$ over the control treatment in the two seasons, respectively. These results may be attributed to that zinc participates in synthesis of auxins and hence, enhances plant growth, also kinetin releases buds from apical dominance (Sarwar et al., 2012 and Salisbury and Ross, 1974).

\section{D - Effect on chemical constituents:}

With respect to the effect of kinetin treatments on $\mathrm{N}, \mathrm{P}, \mathrm{K} \%$, chlorophyll (a), chlorophyll (b) and total carbohydrates content regardless of zinc treatment, data presented in Table $(6,7)$ illustrates that, all kinetin treatments significantly increased $\mathrm{N}$, $\mathrm{P}, \mathrm{K}$ percentage, chlorophyll (a), chlorophyll (b) and total carbohydrates content over the control treatment in an ascending order from the low to the high rate in the two seasons. The highest rate of kinetin $(90 \mathrm{mg} / \mathrm{l})$ significantly raised $\mathrm{N} \%$ by 39.92 and $52.27 \%, \mathrm{P} \%$ by 38.56 and $35.45 \%$ and $\mathrm{K} \%$ by 31.32 and $31.51 \%$, chlorophyll (a) by 34.79 and 



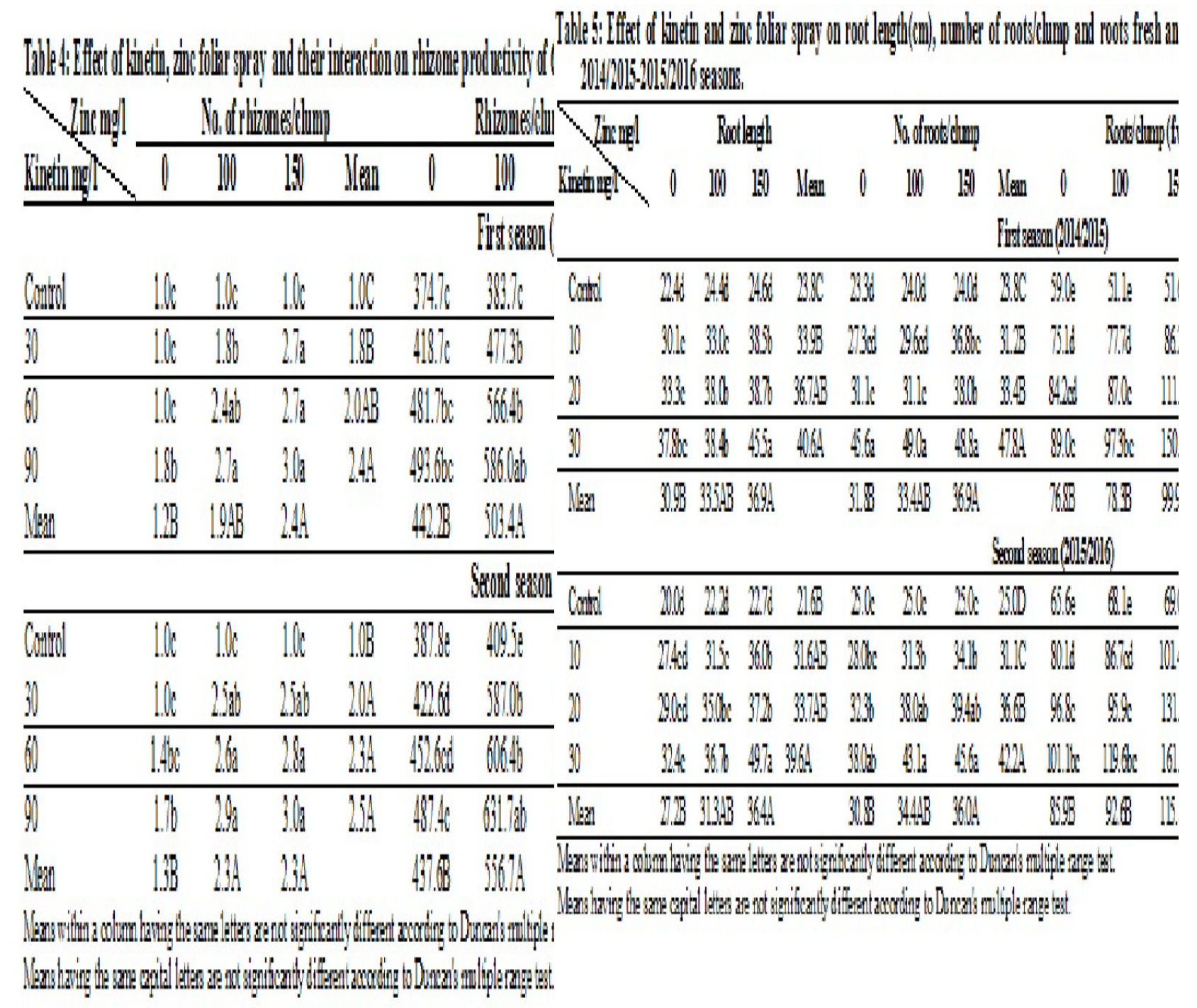


$40.31 \%$, chlorophyll (b) by 31.92 and $40.66 \%$ and total carbohydrates content by (31.32 and $31.39 \%$ ) in both seasons, respectively. These increments may be due to that kinetin promotes some genes, at the cellular level, and induces mitosis as well as development of chloroplast which caused more photosynthetic activity of plant leaves which reflected on more accumulation of metabolites in them especially for the kinetin treatment at the high rate (Yaronskay et al.,2007). Similar results were observed by Ramtin et al., (2016), Youssef and Abd EL-Aal (2014), Khalifa et al., (2011), Eid et al., (2010) and Mohamed (2008).

Regarding the effect of zinc treatments, it is clear from data also that all zinc applications significantly enhanced all chemical constituents comparing with the untreated plants as shown in Table $(6,7)$. The highest rate of zinc $(150 \mathrm{mg} / \mathrm{l})$ significantly increased the $\mathrm{N}, \mathrm{P}, \mathrm{k} \%$, chlorophyll (a), chlorophyll(b) and total carbohydrates content compared to the control treatment in the two seasons. This increasing may be due to that zinc is an essential micronutrient necessary for sugar regulation, protein, starch syntheses and assorted enzymatic activity associated with plant growth and therefore, a low zinc concentration induces accumulation of amino acids and reducing sugars in plant tissue (Khosa et al., 2011). Also these results indicated that zinc proved indispensable for better development of leaf chlorophyll content by fulfilling the micro-nutritional requirements of the plants. The increase in leaf chlorophyll content is directly due to an availability of nutrients at appropriate proportion and in proper time (Fahad et al., 2014). Similarly, Khalifa et al., (2011) and Eid et al., (2010) showed that zinc at rate of $0.75,1.50$ and $3 \mathrm{~g} / \mathrm{l}$ as foliar application significantly increased flowering bulbs characteristics, N, P, K, and total carbohydrates content.

Date presented in Table $(6,7)$ showed the interaction between foliar and zinc treatment. The highest N, P, K \%, chlorophyll (a), chlorophyll (b) and total carbohydrates content resulted from plants treated with kinetin at the rate of $\mathrm{mg} / \mathrm{l} 90$ and the high level of zinc at the rate of $150 \mathrm{mg} / \mathrm{l}$ in the two seasons.

This treatment significantly raised $\mathrm{N} \%$ by 46.33 and $57.12 \%, \mathrm{P} \%$ by 51.86 and $51.38 \%$ and $\mathrm{K} \%$ by 39.67 and $38.30 \%$, chlorophyll (a) by 53.26 and $63.47 \%$, chlorophyll (b) by 36.00 and $47.10 \%$ and total carbohydrates content by 33.01 and $27.89 \%$ comparing to the control treatment in both seasons, respectively. These results may be due to major metabolic processes, cell division, biosynthesis of protein, carbohydrate and chlorophyll, metabolism regulation of nucleic acid, sacharides and lipid metabolism. In addition, kinetin is the essential component of plant cells, affecting the uptake and accumulation of zinc in plant tissues and induced concentration changes of zinc in plants (Kocot et al., 2011 and Sarwar et al., 2012). These results are in accordance with those of Kocot et al., (2011) and Eid et al., (2010).

F- Correlation of Clivia miniata L. Features:

Results indicated that there is a highly significant correlation between all growth parameters of $C$. miniata $\mathrm{L}$ as shown in Table (8). There is a direct relationship between leaf length and leaf number/plant. With the increasing leaf number/plant, leaf length and leaves f.w., leaf induces light absorption ability and also induces the total capacity of plant's photosynthesis process, its growth and, ultimately the overall performance like increasing length, diameter and fresh weight of flowering stalk in addition, number of offset and rhizomes/clump (f.w). Hence, there is a clear correlation between the length, diameters and fresh weight of stalk and No. of florets/flowers and /clump and flowering duration on plant. Naturally, by increasing length, diameter and fresh weight of stalk, No. of florets/flower and /clump and flowering duration on plant will increase. Possibly, the higher number of florets/flower and flowers /clump with zinc and kinetin treatment is due to that kinetin cause transport of many solutes from older parts of the leaves or even from older leaves into the treated zone which caused superior flowering, in addition, zinc might cause superior vegetative growth, stimulatory and catalytic effects of zinc on metabolic processes and ultimately on flower yield and quality (Salisbury and Ross, 1974). Length, number and fresh weight of leaves /plant and length, diameter and fresh weight of stalk/plant resulted in the highest negative correlation with flowering starting date. With an increasing in previous traits thereby, it reduces number of days to flowering. Zinc with kinetin foliar application, induces the offset and rhizomes production, root length, number of roots/clump and roots/clump (f.w).

A significant relationship exists between the length, number and fresh weight of leaves per plant and offset and rhizomes production with an increase in leaves number, thereby, it induces leaf length and leaves fresh weight. Zinc with kinetin foliar application induces the light absorption and photosynthesis, especially in the stalk and leaf and enhances the complete physiological processes, growth and eventually causes offset and rhizomes production (Pazurkiewicz-Kocot et al., 2011, Sarwar et al., 2012 and Salisbury and Ross, 1974). By the importance of zinc in plant structure and in physiological processes and kinetin stimulating lateral bud's growth, they maximize rhizomes and offset production. Hence, it can be concluded that, increasing the concentration of zinc $(150 \mathrm{mg} / \mathrm{l})$ and kinetin $(90$ $\mathrm{mg} / \mathrm{l})$ has a positive impact on overall all growth and performance of Clivia miniata L. plant. 


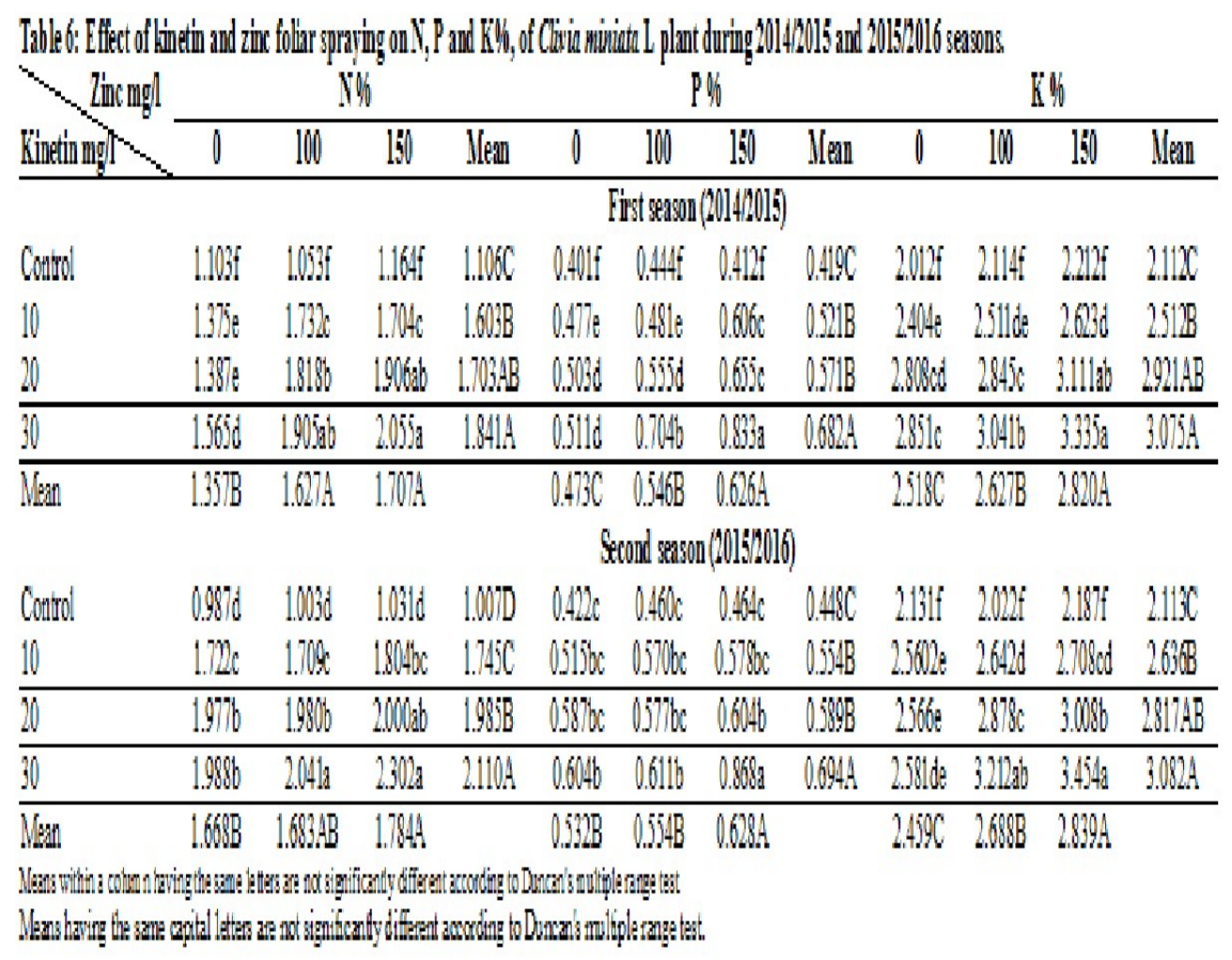




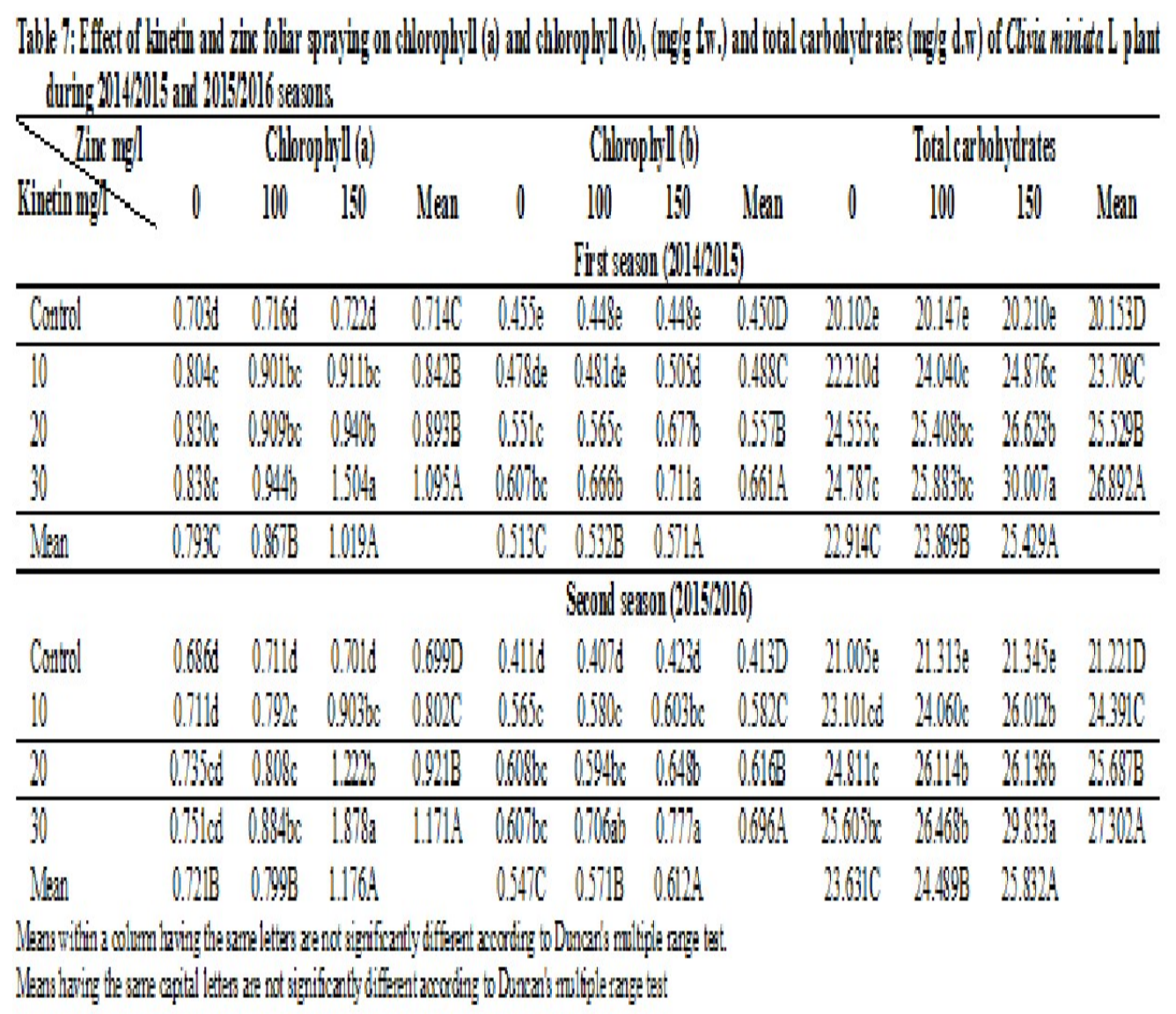




\begin{tabular}{|c|c|}
\hline thithities & 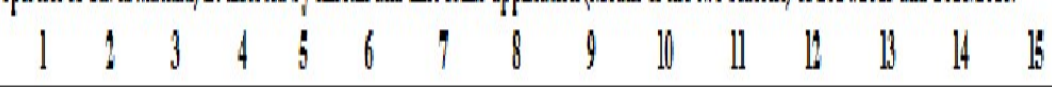 \\
\hline Vistlghth & 1 \\
\hline Lasiblopat & $0.4 \%$ \\
\hline 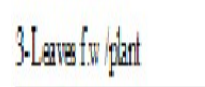 & 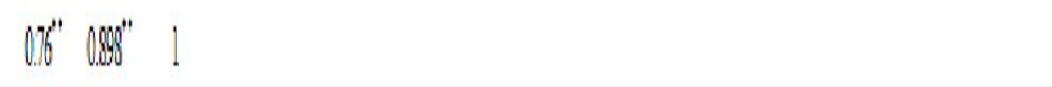 \\
\hline 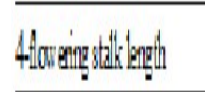 & 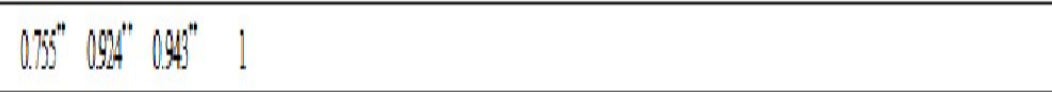 \\
\hline Satdidanter & 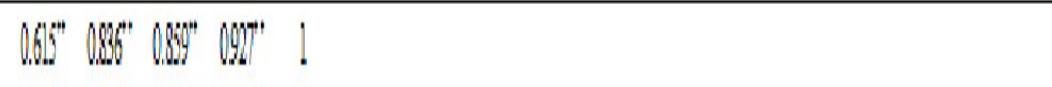 \\
\hline Collefin & $0.00^{\circ} 0.0^{\circ} 0.66^{\circ} 090^{\circ} 09^{\circ} \quad 1$ \\
\hline Maringung & 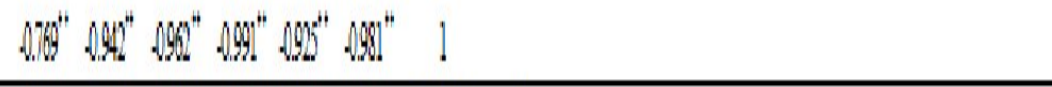 \\
\hline 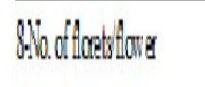 & 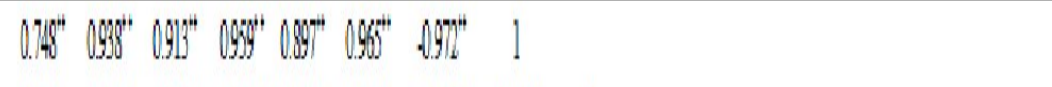 \\
\hline Mlooflowiding & 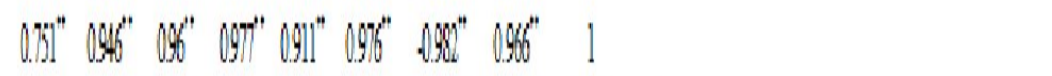 \\
\hline \multicolumn{2}{|c|}{ 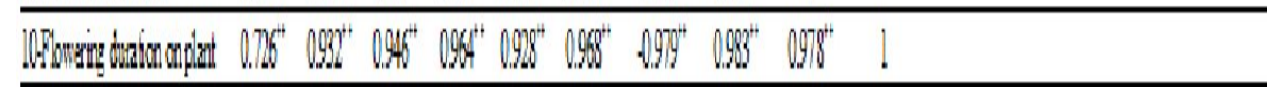 } \\
\hline II. oritats & 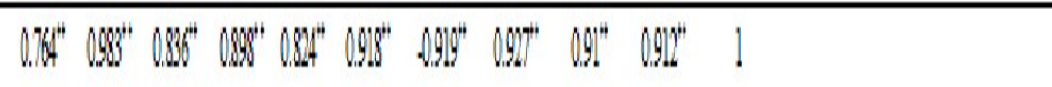 \\
\hline 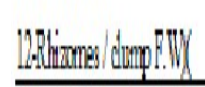 & 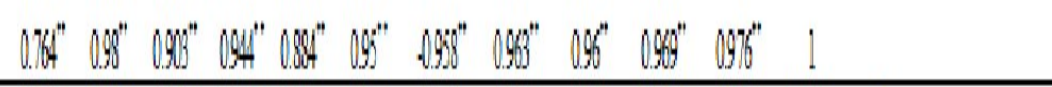 \\
\hline Mharght & 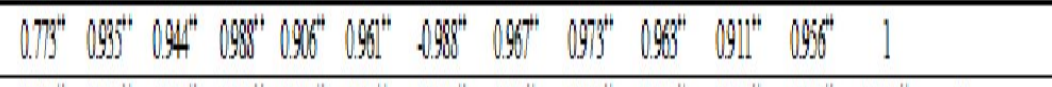 \\
\hline 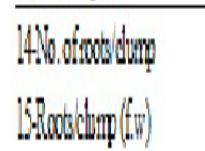 & 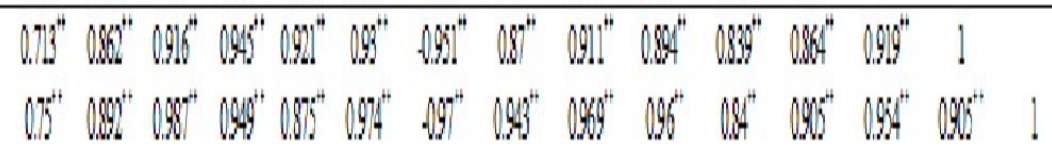 \\
\hline
\end{tabular}





\section{CONCLUSION}

From the findings of the present study, it can be shown that application of combination between kinetin at the rate of $90 \mathrm{mg} / \mathrm{l}$ and zinc the rate of 150 $\mathrm{mg} / \mathrm{l}$ as foliar spray after three weeks of planting Clivia miniata, three times, with three weeks' intervals, not only influenced vegetative growth and flowering in the plant, but also increasing flowering duration, the number of offset produced per plant, rhizomes weight and chemical constituents.

\section{REFERENCES}

Abd El-Aziz, Nahed G. and K. Balbaa, Laila, (2007): Influence of tyrosine and zinc on growth, flowering and chemical constituents of Salvia farinacea plants. Journal of Applied Sciences Research., 3(11): 1479-1489.

Aier, Sh.; S. Langthasa; D. N. Hazarika; B.P. Gautam and R.K. Goswami (2015): Influence of $\mathrm{GA}_{3}$ and $\mathrm{BA}$ on morphological, phenological and yield attributes in Gladiolus Cv. Red Candyman. Journal of Agriculture and Veterinary Science (IOSR)., (8): 6,37-42.

Amling, J.W.; G.J. Keever; J.R. J. Kessler and.J. Eakes (2007): Benzyl Adenine (BA) promotes offshoots formation in Hemerocallis itrina. $\mathrm{J}$ Enviro Hort, 25(1): 9-12.

A.O.A.C. (1990): Official Methods of Analysis of Association of Official Analytical Chemists. Pub. A.O.A.C. INC. Suite 400, 22201 USA Fifteenth Ed., 62-63, 236 and 877-878.

Bezabih, M.; N M. Chauhan; S. T. Hajare and G. Gezahegn (2017): Effects of foliar application of 6-benzylaminopurine on Zingiber officinale Rosc. (Zingerberaceae) boziab variety growth and rhizome production in Ethiopia. Journal of Scientific Research \& Reports.,17(2): 1-8.

Brown, J.D. and O.C. Lilliland (1946): Rapid determination of potassium and sodium in plant material and soil extracts by flame photometry. Proc. Amer. Soc. Hort. Sci., 48: 341-346.

Bubán, T. (2000): The use of benzyladenine in orchard fruit growing: a mini review. Plant Growth Regulation., 32: 381-390.

Carey, D.; B. Whipker; I. M.Call and W. Buhler (2008): Benzyl adenine foliar sprays increase offsets in Sempervivum and Echeveria. J. Hort. Sci., 53: 19-21.

Cheema, G.S. and D.P. Sharma, (1982): In vitro propagation of apple rootstocks. Int. Hort. Congr XXI. Hamburg, German Federal Republic, Int. Soc. Hort. Sci. Vol. 1: 1035 (Chem. Abst., 52: 7692).
Devi1, S. R.; R. Thokchom and U.C. Singh (2017): Growth, flowering and yield of tuberose (Polianthes tuberosa L.) cv. single as influenced by foliar application of $\mathrm{ZnSO} 4$ and CuSO4. Int. J. Curr. Microbiol. App. Sci., 6(10): 735-743.

Eid, R. A.; R.K.M. Khalifa and S.H.A. Shaaban (2010): Effect of foliar application of zinc and benzyladenine on growth, yield and chemical constituents of tuberose plants. Research Journal of Agriculture and Biological Sciences., 6 (6): 732-743.

Fahad, S.; Kh. M. Ahmad, M. A. Anjum, and S. Hussain (2014): The effect of micronutrients (B, $\mathrm{Zn}$ and $\mathrm{Fe}$ ) foliar application on the growth, flowering and corm production of Gladiolus (Gladiolus grandiflorus L.) in calcareous soils. J. Agr. Sci. Tech., 16: 16711682.

Ghatas, Y. A. (2015): Response of Hemerocallis aurantiaca plants to kinetin and chemical fertilization treatments. Middle East Journal of Agriculture Research., 4(4): 650-659.

Halder, N. K.; M. Rafiuddin; M. A. Siddiky; R. Gomes and K. A. Begum (2007a):Performance of Gladiolus as influenced by boron and zinc. Pak. J. Biol. Sci., 10: 581- 585.

Hembrom, R. and A.K. Singh (2015): Effect of iron and zinc on growth, flowering and bulb yield in Lilium. Inter. J. Agric, Envi and Biotech., 8(1): 61-64.

Herbert, D.; J. Philipps and R.E. Strange (1971): Determination of total carbohydrates. Methods in Microbiology., 5(8): 290-344.

Khalifa, R.KH.M.; S.H.A. Shaaban and A. Rawia. (2011): Effect of foliar application of zinc sulfate and boric acid on growth, yield and chemical constituents of Iris plants. Ozean journal of Applied Science., 4(2): 129-144.

Khalighi, A.; Y. Hojati; M. Babalar and R. Naderi (2005): Effects of nutrition solutions, cytokinin and soil texure on bulb growth, quality of bulb and number of bulblet in Drawin hybrid tulip Apeldoorn. Journal of Pajoush and Sazandegi., 73: 58-64.

Khosa, S.S; A. Younis; A. Rayit; S. Yasmeen; A. Riaz (2011): Effect of foliar application of macro and micro nutrients on growth and flowering of Gerbera jamesonii L. Amer. Euras. J. Agri. Envio. Sci., 11: 736-757.

Kocot, K. P.; A. Kita and A. Haduch (2011): The effect of kinetin on the chlorophyll pigments content in leaves of Zea mays.L seedlings and accumulation of some metal ions. Inzynieriai Ochrona Srodowiska., 14 (4): 397-409. 
Koopowitz, H. (2002): Clivias. Timber Press, Portland, USA. L EWIS, A. C., and G. A. LIPANI. 1990. Learning and flower use in butterflies: hypotheses from honey bees. In E. A. Bernays [ed.], Insect-plant Interactions, 95110. CRC Press, Boca Raton, Florida, USA.

Kumar, M.; T. K. Chattopadhyay and D. K. Das (2003): Effect of foliar application of zinc, copper and iron on the yield and quality of Gladiolus grandiflorus cv. Mirela. Journal of Interacademicia., 5(3): 300-303.

Maerschel, R.; B. Kearsley; R. Tomlinson, and J. Wright (2007): Zinc nutrition and plant growth, Available in website. www.spraygro.com.au.

Mohamed, Y. F.Y. (2017): Effect of some growth stimulants on growth, flowering and postharvest quality of Aster (Symphyotrichum novi-belgii L.) cv. Purple Monarch. Middle East Journal of Agriculture Research., 6(2): 264-273.

Mohamed, Y.F., (2008): The effect of certain agricultural postharvest treatments on some ornamental plants. M.Sc. Thesis, Faculty of Agric., Moshtohor, Benha University.

Neetu; R. Kumar and A.K. Singh (2016): Effect of different kinetin concentration on growth and flowering attributes in gladiolus cultivars. Agric. Sci. Digest., 36 (4): 319-322.

Page, A.L. Edit (1982): Methods of soil analysis, part $2.2^{\text {nd }}$ edition. Am. Soc. of Agronomy, Madison, Wisconsin, U S A.

Piper, C.S. (1947): Soil and Plant Analysis. The University of Adelaide, Adelaide, Australia.

Ramtin, A.; S. Kalatejari; R. Naderi and M. Matinizadeh (2016): Effect of benzyladenine and salicylic acid on biochemical traits of two cultivars of carnation. Journal of Experimental Biology and Agricultural Sciences., 4 (4):427434.

Reddy, G.V.S and M. B. N. Rao (2012): Precision foliar application of zinc to improve the growth and yield of Gladiolus. Proceeding of AIPA, India.,44-45. Online available at http://insait.in/aipa2012/ articles/072.pdf.

Sable, P.B.; U.R. Ransingh and D.P. Waskar (2015): Effect of foliar application of plant growth regulators on growth and flower quality of gladiolus cv. 'H.B.Pitt'. J. Horticulture., 2:141. DOI: 10.4172/23760354.1000141.

Salisbury, F.B. and C.W. Ross (1974): Plant Physiology. Publishing Inc. Belmont. California, $2^{\text {nd }}$ ed., 422. Pp.
Sardoei, A.S.; H. Sarhadi; P Rahbarian; M.R. Yazdi1; M. Arbabi and M. Jahantigh (2013): Effect of gibberellic acid and benzyladenine growth regulators on offsets production of Aloe barbadensis at greenhouse conditions. International Journal of Advanced Biological and Biomedical Research., 1 (11): 1457-1465.

Sarwar M, G. Jilani; E. Rafique; M.E. Akhtar and A.N. Chaudhry (2012): Impact of integrated nutrient management on yield and nutrient uptake by maize under rained conditions. Pakistan Journal of Nutrients., 11: 27-33.

Schmulling, T. (2002): New insights into the functions of cytokinins in plant development. Journal of Plant Growth Regular., 21:40-49.

Shah, S.T.; S. Ullah; N.Khan; M. Sajid; A. Rab; N. Amin; A. Iqbal; M. Iqbal; S. Haq; Sh. Rahman1; F. A. Shah and S. Rawan (2015): Effect of zinc as a foliar spray on growth and flower production of marigold (Tagetes erecta L.) Academia Journal of Agricultural Research., 4(3): 140-144.

Sharma, U. B. (2014). Effect of biofertilizer and zinc on gladiolus (Gladiolus grandiflorus L.). Ph.D. Thesis, Faculty of Botany Jiwaji University, Gwalior (M.P.).

Snedecor, G.W. and W.G. Cochran (1972): "Statistical Methods" 6th ed., Iowa Univ. Press. Ames. Iowa, U.S.A.

Troug, E. and A.H. Meyer (1939): Improvement in denies colorimetric method for phosphorus and arsenic 1st Eng. Chem. Anal. Ed., 1: 136139.

Wang, P; H. H. Yuan; X. Zhang; Y. P. Li; L. Q. Shang; and Z. Yin (2014): Novel lycorine derivatives as anticancer agents: Synthesis and in vitro Biological Evaluation. Molecules., (19): 2469-2480.

Yaronskay E.B.; E.R. Gritskevich; N.L. Trukhanovets and N.G. Averina (2007): Effect of kinetin on early stages of chlorophyll biosynthesis in streptomycin-treated barley seedlings, Russian Journal of Plant Physiology., 54, 388-395.

Youssef, A. S. M. and H. M. Ismaeil, Faten, (2009): Response of clivia miniata plant to light intensity and kinetin. Benha University. Annals of Agric. Sci., Moshtohor., 47(2): 2334.

Youssef, A.S.M. and M.A. Mady (2013). Influence of light intensity and benzyladenine on growth performance of Aspidistra elatior Blume plant. Research Journal of Agriculture and Biological Sciences, 9(5): 248257. 
Youssef, A.S.M. and M.M.M. Abd El-Aal (2014): Effect of kinetin and mineral fertilization on growth, flowering, bulbs productivity, chemical compositions and histological features of Hippeastrum vittatum plant. J. Plant Production, Mansoura Univ., 5 (3): 357 381.
Zhifei .C; D. Yu; F. Shilong; Z. Gaochuan; P. Yanyan; B. Meimei; T. Jian; S. Bingxue; G. Pengda; Y. Ping; Z. Quansheng (2013): "Lycorine hydrochloride selectively inhibits human ovarian cancer cell proliferation and tumor neovascularization with very low toxicity". Toxicology Letters., (218): 174-185.

\title{
تاثير الرش بالكينتين والزنك علي أداء النمو في نبات الكليفيا
}

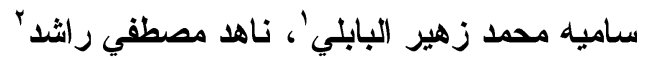

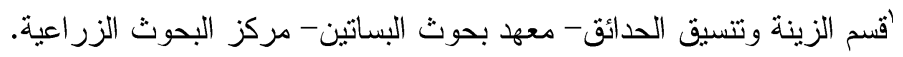

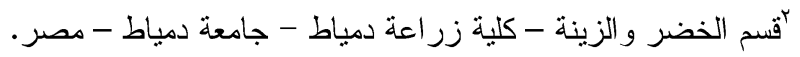 \\ الملخص العربي
}

تم إجر اء هذه التجربة في محطة بحوث البساتين بسخا بمحافظة كفر الثيخ مصر خلال موسـمين متعــاقبين

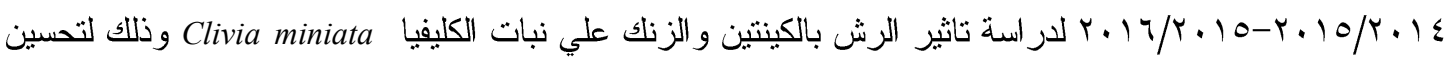
أداء النمو وزيادة الريزومات الجديده المتكونة.

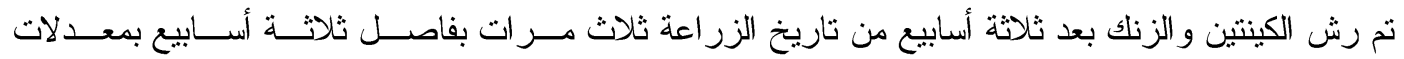

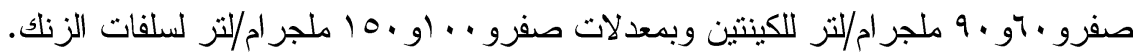

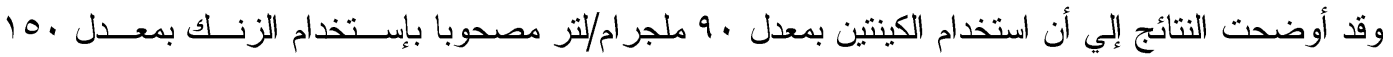

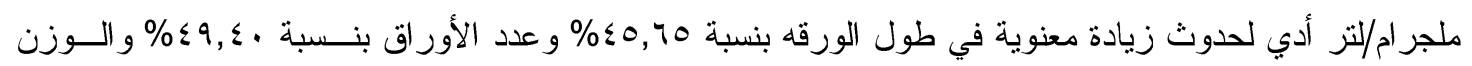

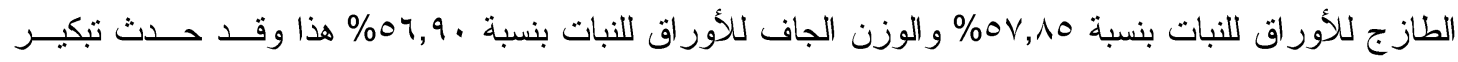

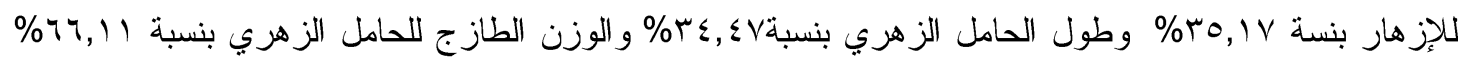

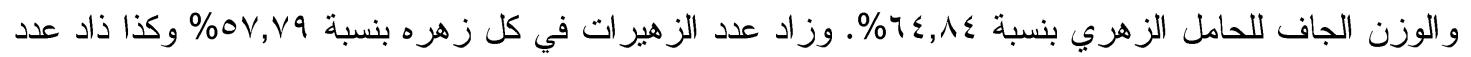

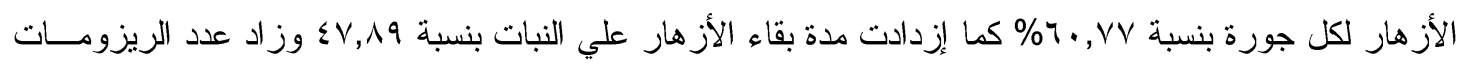

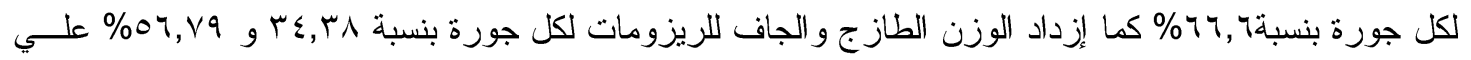
التو الي.

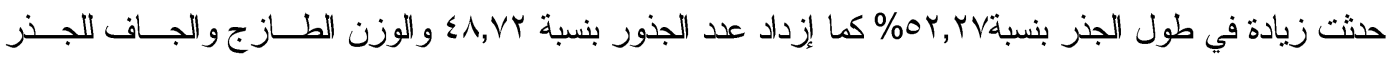

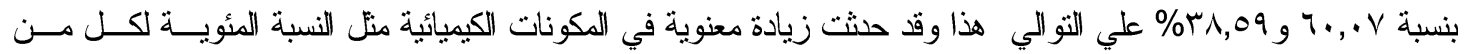

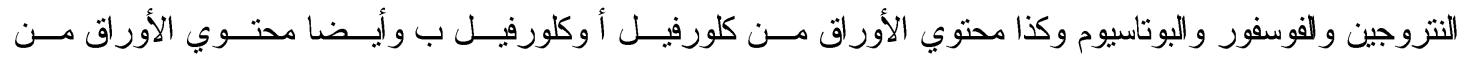

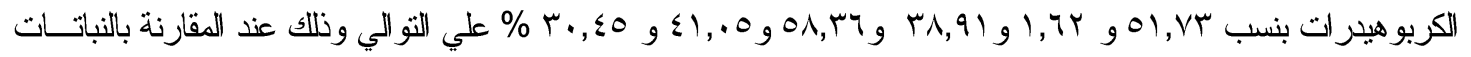
الغير معاملة.

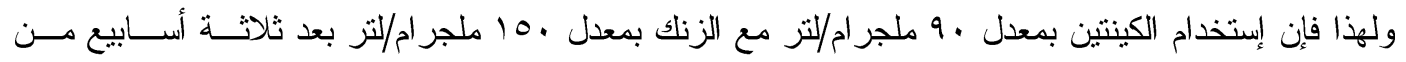

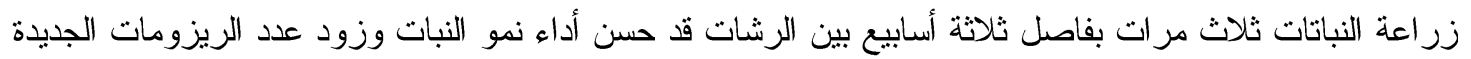
المتكونة في الجورة تحت الظروف المحلية. 